\title{
Relevance of vitamin D deficiency in patients with chronic autoimmune atrophic gastritis: a prospective study
}

\author{
Sara Massironi ${ }^{1}$, Federica Cavalcoli ${ }^{1,2^{*}}$, Alessandra Zilli ${ }^{1,2}$, Alessandro Del Gobbo ${ }^{3}$, Clorinda Ciafardini ${ }^{1}$, \\ Susanna Bernasconi ${ }^{1}$, Irene Felicetta ${ }^{4}$, Dario Conte ${ }^{1}$ and Maddalena Peracchi ${ }^{1}$
}

\begin{abstract}
Background: Chronic autoimmune atrophic gastritis (CAAG) is an autoimmune disease characterized by hypo /achlorhydria. A role of CAAG in the pathogenesis of nutritional deficiencies has been reported, therefore we hypothesized a possible association between CAAG and 25-OH-Vitamin D [25(OH)D] deficiency. Aim of the present study is to evaluate the prevalence of 25(OH)D deficiency in CAAG patients. Methods: 87 CAAG patients (71 females; mean age $63.5 \pm 12.8$ years) followed at our Centre from January 2012 to July 2015 were consecutively evaluated. $25(\mathrm{OH}) \mathrm{D}$, vitamin $\mathrm{B}_{12}$, parathormone, and calcium were measured in all the CAAG patients. The results were compared with a control group of 1232 healthy subjects.

Results: In the CAAG group the mean 25(OH)D levels were significantly lower than in the control group (18.8 vs. $27.0 \mathrm{ng} /$ $\mathrm{ml}, p<0.0001) .25(\mathrm{OH}) \mathrm{D}$ levels $<20 \mathrm{ng} / \mathrm{ml}$ was observed in 57 patients, while levels $<12.5 \mathrm{ng} / \mathrm{ml}$ in 27 patients. A significant correlation between vitamin $B_{12}$ values at diagnosis and 25(OH)D levels was observed $\left(r_{s}=0.25, p=0.01\right)$. Interestingly, the CAAG patients with moderate/severe gastric atrophy had lower $25(\mathrm{OH}) \mathrm{D}$ values as compared to those with mild atrophy (11.8 vs. $20 \mathrm{ng} / \mathrm{ml} ; p=0.0047)$. Moreover, the 25(OH)D levels were significantly lower in CAAG patients with gastric carcinoid as compared to those without gastric carcinoid (11.8 vs. $19.8 \mathrm{ng} / \mathrm{ml} ; p=0,0041)$.

Conclusion: Data from the present study showed a significant reduction of 25(OH)D levels in CAAG patients and a possible impairment of vitamin D absorption in CAAG may be postulated. Any implication to the genesis of gastric carcinoids remains to be elucidated.
\end{abstract}

Keywords: Chronic autoimmune atrophic gastritis, Vitamin D deficiency, Gastric carcinoid, Bone health, Osteoporosis

\section{Background}

Chronic autoimmune atrophic gastritis (CAAG) is an immune-mediated inflammatory condition involving the parietal cells in the gastric fundus and body $[1,2]$. Parietal cells secrete intrinsic factor and hydrochloric acid, via the $\mathrm{H}+/ \mathrm{K}+$ adenosine triphosphatase proton pump, and are the main determinant of gastric acidification. The chronic inflammation results in mucosal atrophy with a progressive destruction and ultimate complete

\footnotetext{
*Correspondence: cavalcoli.federica@gmail.com

'Gastroenterology and Endoscopy Unit, Fondazione IRCCS Ca' Granda Ospedale Maggiore Policlinico, Milan, Italy

${ }^{2}$ Department of Pathophysiology and Transplantation, Università degli Studi di Milano, Milan, Italy

Full list of author information is available at the end of the article
}

loss of parietal cells [3], increase in gastric $\mathrm{pH}$, hypergastrinemia and intrinsic factor deficiency [4].

Intrinsic factor is a co-factor essential for vitamin B12 absorption in the terminal ileum and its deficiency in CAAG leads to vitamin B12 deficiency $[5,6]$. In this setting, also iron insufficiency and iron deficiency anemia have been recently observed, especially in premenopausal women $[7,8]$. The relevance of physiological gastric acid secretion for iron absorption has been suggested by several authors. In fact, nutritional iron is usually bound to proteins and requires the gastric acidification for its solubilization and uptake [9]. Furthermore, an increased incidence of different vitamins and micronutrients deficiency (e.g. ascorbic acid $\mathrm{C}$ and folate) in CAAG was reported [10-12]. It has been postulated that hypochlorhydria and bacterial overgrowth 
in CAAG patients may cause a decreased absorption or increased loss of nutrients in the stomach [11].

A higher incidence of osteopenia and osteoporosis in conditions determining gastric hypochlorhydria, such as gastric resection [13], proton pump inhibitors (PPIs) therapy and CAAG [14-17] has been suggested. However, the pathogenic mechanism leading to these alterations has not been clarified yet. A few studies have reported about a reduced absorption of calcium in patients affected by CAAG $[18,19]$, while a study by Eastell et al. did not find any significant differences in calcium absorption in CAAG patients as compared with controls [20]. Interestingly, two studies have recently reported an association between CAAG and vitamin D deficiency $[21,22]$ and a possible role of vitamin D deficiency in the increased risk of osteopenia/osteoporosis in these patients has been proposed.

Therefore, a possible role of CAAG in determining a vitamin $\mathrm{D}$ deficiency could be hypothesized, however, to date there is lack of studies investigating the relevance of vitamin D deficiency in CAAG patients.

Objective of present study was to prospectively establish the prevalence of 25-OH-Vitamin D $(25(\mathrm{OH}) \mathrm{D})$ deficiency in a cohort of patients with CAAG. Secondary aims were to evaluate possible association between $25(\mathrm{OH}) \mathrm{D}$ levels and histological findings as well as between $25(\mathrm{OH}) \mathrm{D}$ and vitamin B12 levels. To the best of our knowledge, this is the first study aimed at investigating the presence of vitamin D deficiency in CAAG patients.

\section{Methods}

From January 2012 to September 2015, 87 patients with histologically confirmed CAAG followed at our Gastroenterology and Endoscopy Unit, Fondazione IRCCS $\mathrm{Ca}^{\prime}$ Granda Ospedale Maggiore Policlinico of Milan, Italy (16 males and 71 females; mean age $64 \pm 13$ years) were consecutively evaluated.

Moreover, a control group of 1232 healthy subjects (276 males and 956 females, mean age $62.3 \pm 13.2$ years) referred to the "Fondazione IRCCS $\mathrm{Ca}^{\prime}$ Granda Ospedale Maggiore Policlinico of Milan as outpatients for routine laboratory tests was matched for age and gender with the patient group. The criteria for exclusion for both groups were: primary hyperparathyroidism, abnormal calcium values, ongoing vitamin $\mathrm{D}$ supplementation or other medication that can interfere with calcium metabolism, renal failure, pancreatic insufficiency, gastrointestinal disease causing malabsorption (e.g. coeliac disease and inflammatory bowel disease), severe hepatic failure, and concomitant malignancy.

All the subjects, after full explanation of the purpose and nature of all procedures used, gave their written informed consent to participate in the study, which was approved by the local Ethics Committee.
All the CAAG patients underwent initial assessment including upper gastrointestinal endoscopy with complete biopsy sample and blood tests with APCA, anti-intrinsic factor antibodies and fasting gastrin determination. The diagnosis of CAAG was established based on the histological confirmation of gastric body mucosal atrophy and/or enterochromaffin-like (ECL) cell hyperplasia, associated with fasting hypergastrinemia and/or presence of APCA or anti-intrinsic factor antibodies.

In case of $25(\mathrm{OH}) \mathrm{D}$ deficiency (defined when dealing with values $<20 \mathrm{ng} / \mathrm{mL}$ ), patients were given cholecalciferol supplementation, with a loading dose of $300,000 \mathrm{U} /$ month for the first 2 months and then 100,000 U every 4 months and interrupted in case of values exceeded $60 \mathrm{ng} / \mathrm{ml}$.

\section{Laboratory investigations}

In all CAAG patients, the levels of total and ionized calcium $\left(\mathrm{Ca}^{2+}\right)$, albumin, phosphate $(\mathrm{P})$, intact $\mathrm{PTH}$, $25(\mathrm{OH}) \mathrm{D}$, creatinine, vitamin $\mathrm{B}_{12}$, gastrin and $\mathrm{CgA}$ were measured in venous samples obtained after overnight fasting; anticoagulant-free tubes were used for the serum samples and tubes containing EDTA ( $1 \mathrm{mg} / \mathrm{mL}$ of blood) or heparin were utilized for the plasma ones. Serum calcium, albumin, creatinine and urinary calcium and creatinine were measured by standard colorimetric techniques. Total calcium levels were corrected using serum albumin measurements. Plasma ionized calcium was measured using a potentiometric method (Radiometer ABL System 625, Copenhagen, Denmark) on heparinized blood samples within $30 \mathrm{~min}$ from blood collection (reference range: 1.15-1.29 mM). Serum intact PTH was measured by chemiluminescence (Elecsys Intact PTH assay, F. Hoffmann-La Roche, Basel, Switzerland) with a sensitivity of $4.0 \mathrm{pg} / \mathrm{mL}$. 25(OH)D was measured by using a commercial available kit (LIAISON $^{\bullet}$ 25-OH Vitamin D TOTAL Assay ref. 310,600, DiaSorin Inc., Stillwater, MN, USA).

\section{Histological examination}

Upper gastrointestinal endoscopy was performed by trained endoscopists using standard endoscopes (Olympus, Japan and Pentax, Japan). Extensive gastric biopsies ( 2 from the antrum, 2 from the corpus, and 2 from the fundus, larger curvature, in addition to any endoscopically evident mucosal lesion) were obtained in all the cases. Formalin-fixed-paraffin-embedded biopsies were stained with hematoxylin-eosin and Alcian blue-periodic acidSchiff (PAS) histochemical staining in order to evaluate morphological features. Immunohistochemistry with antibodies anti-chromogranin A, gastrin and Ki-67, when required, was performed using the automatic system DAKO Omnis (Agilent, Santa Clara, California, USA) according 
to the manufacturer's instructions. All the samples were evaluated by an experienced pathologist.

The degree of gastritis was classified according to the Sydney classification system [23] which provides guidelines on how to incorporate etiology (i.e. H.pylori, autoimmune), topography (antrum, corpus) and morphological features (chronic inflammation, activity, atrophy and intestinal metaplasia) in pathologist reports of gastric biopsies. More in detail, gastric atrophy defined as loss of appropriate glands, has been classified in mild (reduction of appropriate glands from 1 to $30 \%$ ), moderate (loss of glands from 31 to $60 \%$ ) and severe (loss of glands $>60 \%$ ) (Table 1) $[23,24]$.

The status of the enterochromaffin-like (ECL) cells was classified according to Solcia et al. [25] as: hyperplastic changes in case of ECL cells proliferation < $150 \mu \mathrm{m}$ (diffuse, linear, micronodular, or adenomatoid hyperplasia); dysplastic lesions for ECL proliferation between 150 and $500 \mu \mathrm{m}$ (microinvasive lesions, enlarged or fused micronodules, and nodular growth), and neoplasia for ECL proliferation $>500 \mu \mathrm{m}$ (intramucosal or invasive carcinoids). Minute ECL cell nests characterized by small aggregates less than $50 \mu \mathrm{m}$ in diameter were separated from true hyperplastic micronodules and were not considered as signs of hyperplasia [26].

\section{Patients characteristics'}

According to the Sydney classification [23], 37 patients had mild, 34 moderate and 16 severe chronic gastritis. The status of the entero-chromaffin-like (ECL) cells was classified according to Solcia et al. [25]. In our series, 24 patients had no cell hyperplasia, 23 had linear hyperplasia and 17 had micronodular hyperplasia, whereas 23 patients had type 1 gastric carcinoids (GC1), of variable size (range $0.2-3 \mathrm{~cm}$ ), single in 10 cases and multiple in 13 .

Table 1 Atrophy in the gastric mucosa: histological classification and grading [26]

\begin{tabular}{|c|c|c|c|c|}
\hline \multicolumn{5}{|c|}{ 0. Absent $(=$ score 0$)$} \\
\hline \multicolumn{5}{|c|}{ 1. Indefinite (no score is applicable) } \\
\hline \multirow[t]{4}{*}{$\begin{array}{l}2 . \\
\text { Present }\end{array}$} & $\begin{array}{l}\text { Histological } \\
\text { type }\end{array}$ & $\begin{array}{l}\text { Location \& } \\
\text { key lesions }\end{array}$ & & Grading \\
\hline & & Antrum & Corpus & \\
\hline & $\begin{array}{l}\text { 2.1. Non- } \\
\text { metaplastic }\end{array}$ & $\begin{array}{l}\text { Gland } \\
\text { disappearan } \\
\text { (shrinking) } \\
\text { Fibrosis of } \\
\text { the lamina } \\
\text { propria }\end{array}$ & & $\begin{array}{l}\text { 2.1.1. } \text { Mild = G1 } \\
\text { (1-30\%) } \\
\text { 2.1.2. Moderate = G2 } \\
\text { (31-60\%) } \\
\text { 2.1.3. Severe = G3 } \\
(>60 \%)\end{array}$ \\
\hline & $\begin{array}{l}2.2 . \\
\text { Metaplastic }\end{array}$ & $\begin{array}{l}\text { Metaplasia: } \\
\text { - Intestinal }\end{array}$ & $\begin{array}{l}\text { Metaplasia: } \\
\text { - Pseudo- } \\
\text { pyloric } \\
\text { - Intestinal }\end{array}$ & $\begin{array}{l}\text { 2.2.1. Mild = G1 } \\
(1-30 \%) \\
\text { 2.2.2. Moderate = G2 } \\
(31-60 \%) \\
\text { 2.2.3. Severe = G3 } \\
(>60 \%)\end{array}$ \\
\hline
\end{tabular}

Representative microphotographs of our series are depicted in Fig. 1.

Anti-parietal cell antibodies (APCA) were present in 79 patients (91\%). The associated reported autoimmune diseases were: primary hypothyroidism in 30 patients, vitiligo in four, Graves' disease in two, mixed connective tissue disease in two, multiple sclerosis, psoriasis, alopecia, PGA type 1, myasthenia gravis and scleroderma were reported in one patient each. Previous Helicobacter pylori (H. pylori) infection was reported in 20 CAAG patients, all of them having been treated with successful eradication. Active infection was present in two patients, who have been treated successfully.

Among the CAAG patients, dual-energy X-ray absorptiometry (DXA) to evaluate bone mineral density (BMD) $\left(\mathrm{g} / \mathrm{cm}^{2}\right)$ was available for 39 out of 87 patients. Lumbar spine BMD was measured using the average value for L1 to L4. Femur BMD was measured at femoral neck. Low bone density and osteoporosis were diagnosed using the World Health Organization criteria $(-2.5<\mathrm{T}$-score $<-$ 1.0 and $\mathrm{T}$-score $\leq-2.5$ respectively).

\section{Statistical analysis}

Continuous variables were reported as mean \pm standard deviation (SD) or median and range; categorical variables were reported as count (percentage). All data were tested for distribution normality via the KolmogoroffSmirnoff test. The differences between groups were assessed with the Mann-Whitney and Kruskal-Wallis test as appropriate. Differences between percentages were evaluated by Fisher's exact test. The relationships between variables were determined by Spearman's coefficient. A $p$ value $<0.05$, two-sided, was considered statistically significant. The analyses were carried out by software Graph Pad Prism version 5.00 and Graph Pad State Mat version 2, for Windows (GraphPad Software, San Diego, California, USA).

\section{Results}

The CAAG group showed significantly lower $25(\mathrm{OH}) \mathrm{D}$ mean levels $(18.8 \pm 9.7 \mathrm{ng} / \mathrm{ml})$ compared with the control group $(27.0 \pm 16.3 \mathrm{ng} / \mathrm{ml})(p<0.0001) .25(\mathrm{OH}) \mathrm{D}$ deficiency, defined as $25(\mathrm{OH}) \mathrm{D}$ levels lower than $20 \mathrm{ng} / \mathrm{ml}$, was observed in $57(66 \%)$ of the 87 CAAG patients and in $438(36 \%)$ of the patients in the control group, (Fisher's exact test $p<0.0001$ ) (Table 2).

25(OH)D levels lower than $12.5 \mathrm{ng} / \mathrm{ml}$, was present in 27 of 87 patients (31\%) in the CAAG group and in 160 of $1232(13 \%)$ patients in the control group (Fisher's exact test $p<0.0001)$. The mean $25(\mathrm{OH}) \mathrm{D}$ values were not significantly different between female and male patients, neither among CAAG patients (female mean 19.2 vs. male $17.0 \mathrm{ng} / \mathrm{ml}, p=0.65$ ) nor among controls (female mean 26.9 vs. male $27.0 \mathrm{ng} / \mathrm{ml}, p=0.07$ ). A 

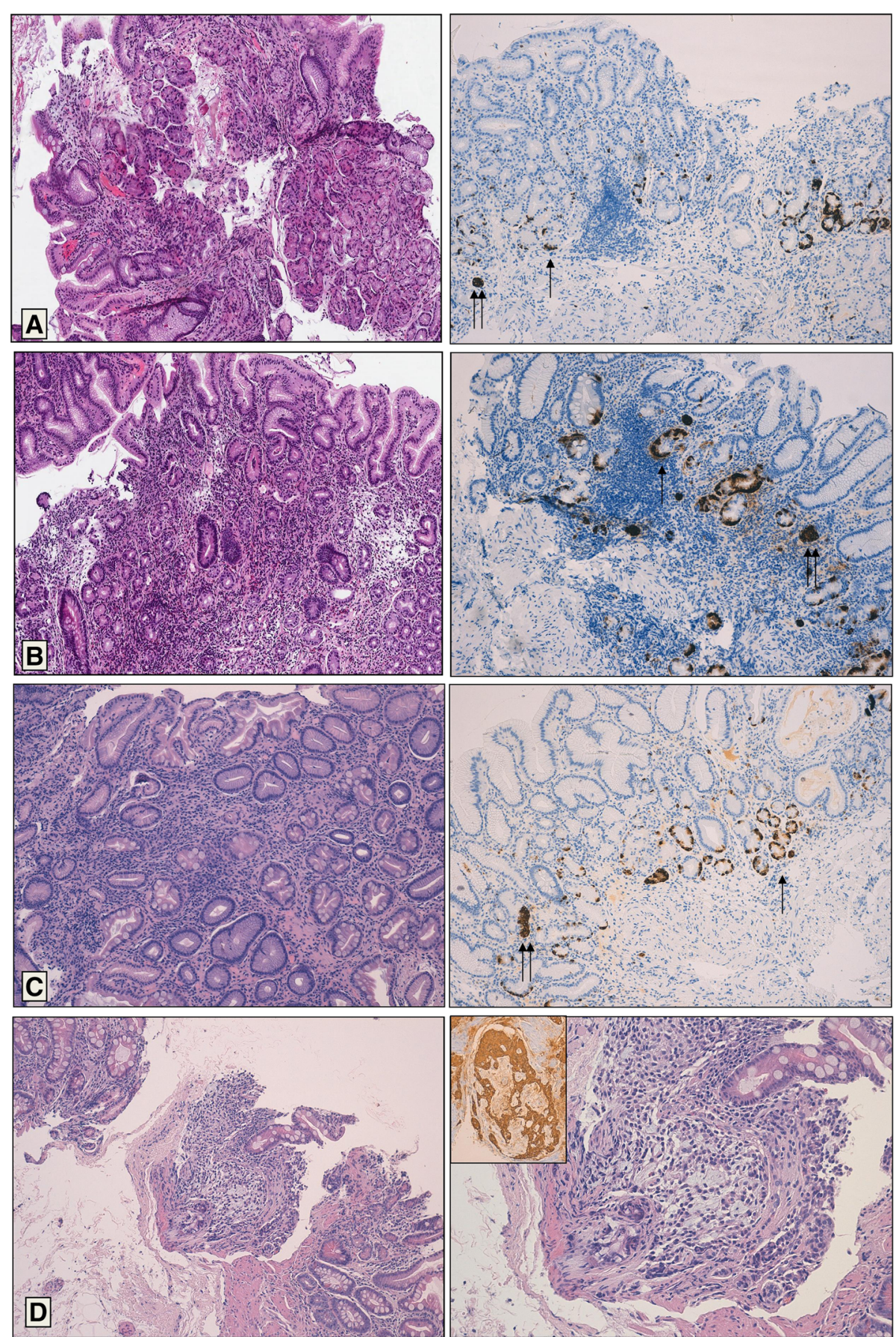

Fig. 1 Histological features of atrophic gastritis. a Mild atrophic chronic gastritis, showing focal loss of mucosal glands associated with mild chronic inflammation (EE 10x). Chromogranin A immunohistochemical stain shows linear (one arrow) and micronodular (two arrows) neuroendocrine cells hyperplasia. b Moderate atrophic chronic gastritis, showing moderate loss of mucosal glands associated with moderate chronic inflammation (EE 10x). Chromogranin A immunohistochemical stain shows linear (one arrow) and micronodular (two arrows) neuroendocrine cells hyperplasia. c Severe atrophic chronic gastritis, showing diffuse and severe loss of mucosal glands associated with mild chronic inflammation (EE 10x). Chromogranin A immunohistochemical stain shows linear (one arrow) and micronodular (two arrows) neuroendocrine cells hyperplasia. $\mathbf{d}$ Gastric carcinoid, characterized by nodular and solid growth pattern of monomorphous neuroendocrine cells (EE 10x left and 20x right), immunoreactive for Chromogranin A (insert) 
Table 2 Demographic and biochemical data of CAAG patients and healthy controls

\begin{tabular}{llll}
\hline & $\begin{array}{l}\text { CAAG patients } \\
(n=87)\end{array}$ & $\begin{array}{l}\text { Healthy control } \\
(n=1232)\end{array}$ & $p$ value \\
\hline Female (\%) & $71(82)$ & $956(76)$ & $\mathrm{ns}$ \\
$\begin{array}{l}\text { Age (years) } \\
\text { Mean } \pm \text { SD }\end{array}$ & $63.5 \pm 12.8$ & $62.3 \pm 13.2$ & $\mathrm{~ns}$ \\
$25(\mathrm{OH}) \mathrm{D} \mathrm{ng} / \mathrm{ml}$ & $18.8 \pm 9.7$ & $27.0 \pm 16.3$ & $<0.0001$ \\
$\begin{array}{l}\text { Mean } \pm \text { SD } \\
25(\mathrm{OH}) \mathrm{D}<20 \mathrm{ng} / \mathrm{ml}\end{array}$ & $57(66 \%)$ & $438(36 \%)$ & $<0.0001$ \\
$\mathrm{n}(\%)$ & & $160(13 \%)$ & $<0.0001$ \\
$25(\mathrm{OH}) \mathrm{D}<12.5 \mathrm{ng} / \mathrm{ml}$ & $27(31 \%)$ & &
\end{tabular}

CAAG chronic autoimmune atrophic gastritis, 25(OH)D 25-OH-Vitamin D, ns not significant

statistical difference in the number of patients diagnosed in summer/spring vs winter/autumn was not observed $(p<0.001)$.

The demographic and biochemical data of CAAG patients with and without vitamin $\mathrm{D}$ deficiency are detailed in Table 3.

In CAAG patients a deficit of vitamin B12, defined as vitamin B12 levels below $190 \mathrm{ng} / \mathrm{ml}$, was present in 28 cases (32\%). In this setting, a significant correlation between vitamin $B_{12}$ values at diagnosis and $25(\mathrm{OH}) \mathrm{D}$ levels was observed $\left(r_{s}=0.25, p=0.01\right)$. In detail, mean $25(\mathrm{OH}) \mathrm{D}$ was lower in patients with vitamin $\mathrm{B}_{12}$ deficiency $(15.9 \pm 9.9 \mathrm{ng} / \mathrm{ml})$ compared with patients without vitamin $\mathrm{B}_{12}$ deficiency $(20.2 \pm 9.7 \mathrm{ng} / \mathrm{ml})(p=0.025)$.

All the CAAG patients had normal serum calcium levels (mean $9.6 \pm 1.8 \mathrm{mg} / \mathrm{dl}$ ) and ionized calcium levels $(1.2 \pm 0.1 \mathrm{mmol} / \mathrm{l})$. Elevation in PTH levels, defined as PTH levels $>65 \mathrm{pg} / \mathrm{ml}$ was observed in 22 of the 87 CAAG patients $(25 \%)$ (mean $74 \pm 24.2 \mathrm{pg} / \mathrm{ml}$ ). In all these cases, proper vitamin D supplementation led to PTH levels normalization, thus the diagnosis of secondary hyperparathyroidism due to vitamin D deficiency was made.

In our series, the CAAG patients with moderate to severe gastric atrophy at histology presented significantly lower $25(\mathrm{OH}) \mathrm{D}$ values than those with mild atrophy $(11.8$ vs. $20 \mathrm{ng} / \mathrm{ml} ; p=0.0047)$. Moreover, 25(OH)D levels were significantly lower in CAAG patients with gastric carcinoid as compared to the group of CAAG patients without ECL hyperplasia or having linear or micronodular ECL hyperplasia (11.80 vs. $19.75 \mathrm{ng} / \mathrm{ml} ; p$ $=0.0041)($ Fig. 2).

A significant inverse correlation $\left(\mathrm{r}_{\mathrm{s}}=-0.25, p=0.032\right)$ between 25(OH)D and BMI was observed in CAAG patients. A direct correlation was observed between $25(\mathrm{OH}) \mathrm{D}$ and circulating vitamin $\mathrm{B}_{12}\left(\mathrm{r}_{\mathrm{s}}=-0.28, p=\right.$ $0.009)$, whereas there was not any significant correlation between $25(\mathrm{OH}) \mathrm{D}$ levels and gastrin levels $(p=0.7)$.

Table 3 Demographic and biochemical data of CAAG patients with and without vitamin D deficiency

\begin{tabular}{|c|c|c|c|}
\hline Patients & $\begin{array}{l}25(\mathrm{OH}) \mathrm{D} \\
\text { deficiency } \\
(n=57)\end{array}$ & $\begin{array}{l}\text { Normal } 25(\mathrm{OH}) \mathrm{D} \\
(n=30)\end{array}$ & $p$ value \\
\hline Female n (\%) & $47(83)$ & $24(80)$ & ns \\
\hline $\begin{array}{l}\text { Age (years) } \\
\text { Mean } \pm S D\end{array}$ & $63.4 \pm 12.8$ & $64.6 \pm 12.9$ & ns \\
\hline $\begin{array}{l}\text { APCA positivity } \\
\mathrm{n}(\%)\end{array}$ & $50(88)$ & $29(97)$ & ns \\
\hline \multicolumn{4}{|l|}{ Atrophy n (\%) } \\
\hline - mild & $24(42)$ & $13(43)$ & ns \\
\hline - moderate & $20(35)$ & $14(47)$ & \\
\hline - severe & $13(23)$ & $3(10)$ & \\
\hline \multicolumn{4}{|c|}{ ECL cell hyperplasia n (\%) } \\
\hline • normal & $17(30)$ & $7(23)$ & ns \\
\hline - linear & $12(21)$ & $11(37)$ & \\
\hline - micronodular & $10(17)$ & $7(23)$ & \\
\hline - gastric carcinoid & $18(32)$ & $5(17)$ & \\
\hline
\end{tabular}




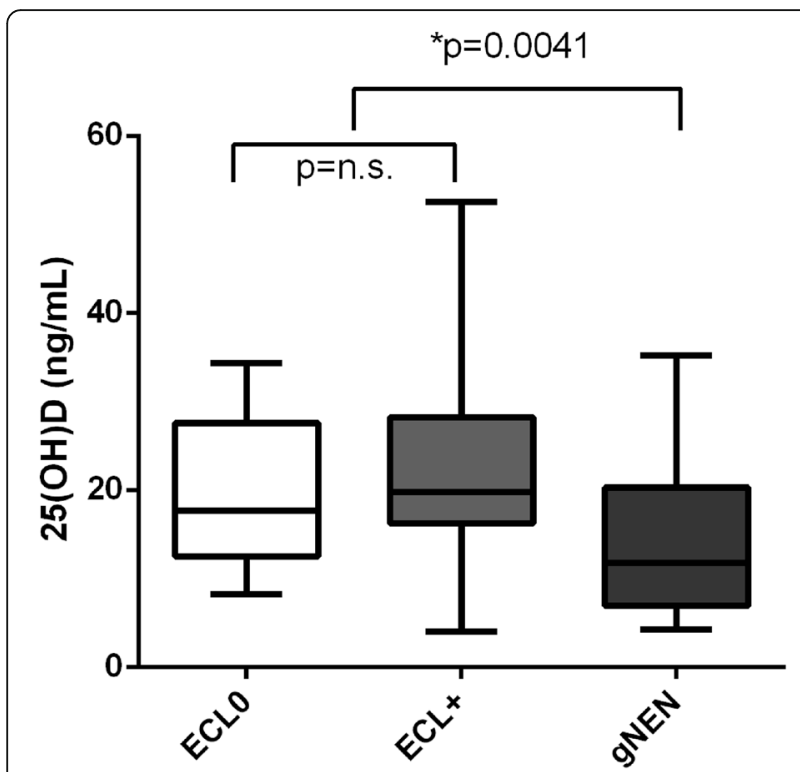

Fig. 2 25(OH)D levels in CAAG patients having absence of ECL hyperplasia (ECLO), linear or micronodular ECL hyperplasia $(E C L+)$ or gastric carcinoid (GC1)

Among the 39 CAAG patients who underwent DXA, 17 patients had osteoporosis, 14 had low bone density/ osteopenia, while in the remaining 5 patients the DXA scan was normal. 25(OH)D levels did not significantly differ among patients with osteoporosis/osteopenia and normal DXA.

\section{Discussion}

The present study has documented significantly lower mean $25(\mathrm{OH}) \mathrm{D}$ values in CAAG patients as compared with outpatient controls. Moreover, in CAAG patients a significantly higher rate of $25(\mathrm{OH}) \mathrm{D}$ deficiency, considering 25(OH)D values lower either than $20 \mathrm{ng} / \mathrm{ml}$ or $12.5 \mathrm{ng} / \mathrm{ml}$, was observed. These results are similar to those observed by Antico et al. [22] that reported lower $25(\mathrm{OH}) \mathrm{D}$ values in CAAG patients when compared to patients with non-specific gastritis or healthy controls. The authors reported 25(OH)D mean levels in CAAG patients to be $9.8 \pm 5.6 \mathrm{ng} / \mathrm{mL}$ versus $21.3 \pm 12.2 \mathrm{ng} / \mathrm{mL}$ in controls. On the basis of their results, the authors speculated that vitamin $\mathrm{D}$ deficiency may play a role in the pathogenesis of the autoimmune processes [22]. In addition a previous study from our group [21] observed an higher rate of hyperparathyroidism secondary to vitamin D deficiency in CAAG patients. On the other hand, Eastell et al. [20] did not show a significant difference in $25(\mathrm{OH}) \mathrm{D}$ values among 21 CAAG patients and healthy controls [20], even though the low number of cases evaluated may have limited the results of their study.

To date the pathogenesis of hypovitaminosis $\mathrm{D}$ in CAAG patients has not been clarified. However, as for other micronutrients [11], a decreased absorption/increased destruction of vitamin $\mathrm{D}$ in the gastrointestinal mucosa due to the hypochlorhydria and bacterial overgrowth might be hypothesized. Interestingly, this is the first study showing significantly lower 25(OH)D values in CAAG with moderate to severe gastric atrophy as compared to those with mild atrophy $(p=0.0047)$. This finding strongly suggests a causal association between the degree of mucosal atrophy and 25(OH)D levels. It may be postulated that in patients with mild atrophy the residual production of gastric acid can preserve a sufficient rate of vitamin $\mathrm{D}$ absorption, which, however, becomes insufficient in more advanced stages of the disease.

The hypothesis of a progressive functional alteration in the gastric mucosa over time has been already proposed with regard to patients with CAAG so as to explain the progression from microcytic anemia to macrocytic anemia $[9,27]$. Indeed, CAAG patients with iron deficiency anemia have been reported to be younger than patients presenting with pernicious anemia. This suggests iron deficiency to be an early manifestation of CAAG, while the depletion of vitamin $B_{12}$ stores appears to take many years longer and to reveal in older patients, when a severe deficiency of the intrinsic factor has been established [9, 27]. Accordingly, in our study CAAG patients' presented a significant correlation between vitamin $B_{12}$ values at diagnosis and $25(\mathrm{OH}) \mathrm{D}$ levels $(p=$ 0.009 ), probably because these levels are both dependent on the residual gastric function and are reduced in the advanced stages of disease.

Interestingly, our study has showed significantly lower 25-OHvitD levels in patients with gastric neuroendocrine neoplasms (NENs) as compared to patients without gastric NENs. The pathogenic mechanism leading to this association has not been fully elucidated yet, however vitamin D has proved to be involved in cell growth, apoptosis, differentiation, cell adhesion, immune regulation, angiogenesis, and metastasis in epithelial tissues $[28,29]$ Therefore, the possible role of hypovitaminosis $\mathrm{D}$ in the development of gastric NENs may be postulated. In the last few years a number of studies have focused on the antineoplastic properties of vitamin D in different solid neoplasms [30-32] and recently a paper from our group showed a significant higher prevalence of vitamin D deficiency among NEN patients [33]. Moreover, in the same study we observed an improved clinical outcome for patients supplemented by vitamin $\mathrm{D}$, reinforcing the hypothesis on an antiproliferative effect of vitamin D supplementation on NEN.

Gastric achlorhydria secondary to gastric surgery, long-term PPI intake or CAAG has been reported to increase the risk of bone health impairment [14]. A recent meta-analysis has shown that PPIs increase the rate of 
any site fractures of $16 \%$ and in particular the risk of hip (30\%) and spine fractures (56\%) [34]. However, to date the studies investigating the occurrence of osteoporosis in the setting of CAAG are rare and inconclusive [20]. In the present series, DXA scan results did not significantly differ between CAAG patients with vitamin D deficiency and those with normal levels. However, this can be owed to the small number of patients who underwent bone densitometry in the present study (39 out of 86 ). Therefore, the exact influence of vitamin D deficiency on osteopenia/osteoporosis in CAAG patients remains to be accurately evaluated. Some previous reports have suggested a reduction of bone density in the lumbar spine of patients with pernicious anemia, even though negative reports have also been published [35-37]. A recent study by Kim et al. has found a significant association between atrophic gastritis and osteoporosis in post-menopausal women aged 60 or older, after adjusting for age, body mass index, triglycerides, cholesterol, alcohol consumption, and smoking status [16]. Interestingly, a previous study had not found a significant association between bone mass density and atrophic gastritis [38], however, the participants in that study were relatively young. Therefore, it is possible that the onset of $25(\mathrm{OH}) \mathrm{D}$ deficiency in patients with CAAG is a long-developing process leading to significant alterations in older patients with a long-standing history of disease.

A decrease in calcium salts dissolution and absorption in non-acidic conditions has been previously suggested as the main pathological mechanism for bone impairment in patients with achlorhydria. Remarkably, the active transcellular absorption of ionized calcium in the duodenum and proximal small intestine represents the most important physiological pathway for calcium absorption and is highly dependent on vitamin D. Thus, it seems possible that the vitamin D deficiency in CAAG patients also explains calcium malabsorption and alterations in bone mineralization.

Possible limitations of our study are the relatively small number of patients evaluated and that $25(\mathrm{OH}) \mathrm{D}$ determination were obtained during outpatient's examination during all the year; however we did not observe a statistical difference in the number of patients diagnosed in summer/spring vs winter/autumn. Strengths of presents study were the use of strict diagnostic criteria for CAAG which enables to obtain a highly homogenous group of study and the centralization of all laboratory tests.

\section{Conclusions}

This study has clearly demonstrated that vitamin D deficiency is more frequent in patients affected by CAAG than in the general population and correlates with the grade of gastric atrophy. The pathogenic mechanism underlying this association has not been fully elucidated, but it is probably due to a decreased absorption of vitamin D secondary to gastric hypo-achlorhydria. Further larger studies are necessary to evaluate the relevance of vitamin $\mathrm{D}$ deficiency in the occurrence of osteopenia and osteoporosis in CAAG patients.

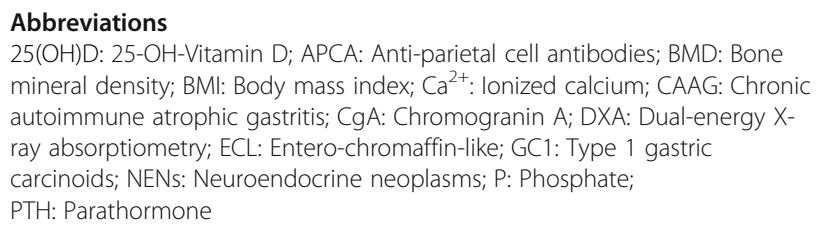

Acknowledgements

Marc Hinxman-Allegri as an English native speaker revised the manuscript for language and style.

\section{Funding}

This research did not receive any specific grant from funding agencies in the public, commercial, or not-for-profit sectors.

\section{Availability of data and materials}

The datasets used and/or analyzed during the current study are available from the corresponding author on reasonable request.

\section{Authors' contributions}

SM planned the work; IF and CC performed the literature search; FC and AZ wrote the first draft of the manuscript; SM, SB and FC edited the subsequent versions of the manuscript; DC and MP critically revised the manuscript for relevant intellectual content. Finally, all authors read and approved the final manuscript.

\section{Ethics approval and consent to participate}

All the subjects, after full explanation of the purpose and nature of all procedures used, gave their written informed consent to participate in the study, which was approved by the Ethics Committee of the Fondazione IRCCS Ca' Granda Ospedale Maggiore Policlinico of Milan.

\section{Consent for publication}

Not Applicable.

\section{Competing interests}

The authors declare that there is no conflict of interest that could be perceived as prejudicing the impartiality of the research reported.

\section{Publisher's Note}

Springer Nature remains neutral with regard to jurisdictional claims in published maps and institutional affiliations.

\section{Author details \\ 'Gastroenterology and Endoscopy Unit, Fondazione IRCCS Ca' Granda Ospedale Maggiore Policlinico, Milan, Italy. ${ }^{2}$ Department of Pathophysiology and Transplantation, Università degli Studi di Milano, Milan, Italy. ${ }^{3}$ Division of Pathology, Fondazione IRCCS Ca' Granda Ospedale Maggiore Policlinico, 20122 Milan, Italy. ${ }^{4}$ Laboratory of Clinical Chemistry and Microbiology, Fondazione IRCCS Ca' Granda Ospedale Maggiore Policlinico, Milan, Italy.}

Received: 5 July 2018 Accepted: 30 October 2018

Published online: 08 November 2018

References

1. Toh BH, van Driel IR, Gleeson PA. Pernicious anemia. N Engl J Med. 1997; 337:1441-8.

2. Toh BH. Diagnosis and classification of autoimmune gastritis. Autoimmun Rev. 2014;13:459-62.

3. Toh BH, Alderuccio F. Pernicious anaemia. Autoimmunity. 2004;37:357-61. 
4. Solcia E, Capella C, Fiocca R, Cornaggia M, Rindi G, Villani L, et al. Exocrine and endocrine epithelial changes in type A and B chronic gastritis. In: Malfertheiner P, Ditschuneit $\mathrm{H}$, editors. Helicobacter pylori, Gastritis and Peptic Ulcer. Berlin: Springer Berlin Heidelberg; 1990. p. 245-58.

5. Wintrobe M, Lee G, Boggs D, Bithell T, Foerster J, Athens J, et al. Megaloblastic and nonmegaloblastic macrocytic anemias. In: Wintrobe $M$, Lee G, Boggs D, Bithell T, Foerster J, et al., editors. Clinical hematology. 8th ed. Philadelphia: Lea \& Febiger; 1981. p. 559-604.

6. Kozyraki R, Cases O. Vitamin B12 absorption: mammalian physiology and acquired and inherited disorders. Biochimie. 2013:95:1002-7.

7. Gonçalves C, Oliveira ME, Palha AM, Ferrão A, Morais A, Lopes Al. Autoimmune gastritis presenting as iron deficiency anemia in childhood. World J Gastroenterol. 2014;20:15780-6.

8. Lagarde S, Jovenin N, Diebold MD, Jaussaud R, Cahn V, Bertin E, et al. Is there any relationship between pernicious anemia and iron deficiency? Gastroenterol Clin Biol. 2006;30:1245-9.

9. Hershko C, Ronson A, Souroujon M, Maschler I, Heyd J, Patz J. Variable hematologic presentation of autoimmune gastritis: age-related progression from iron deficiency to cobalamin depletion. Blood. 2006;107:1673-9.

10. Alt H, Chinn H, Farmer C. The blood plasma ascorbic acid in patients with achlorhydria. Am J Med Sci. 1939;197:222-32.

11. Ludden J, Flexner J, Wright I. Studies on ascorbic acid deficiency in gastric diseases: incidence, diagnosis, and treatment. Am J Dig Dis. 1941;8:249-52.

12. Cavalcoli F, Zilli A, Conte D, Massironi S. Micronutrient deficiencies in patients with chronic atrophic autoimmune gastritis: a review. World J Gastroenterol. 2017;23:563-72.

13. Vilarrasa N, San José P, García I, Gómez-Vaquero C, Miras PM, de Gordejuela $A G$, et al. Evaluation of bone mineral density loss in morbidly obese women after gastric bypass: 3-year follow-up. Obes Surg. 2011;21:465-72.

14. Sipponen P, Harkonen M. Hypochlorhydric stomach: a risk condition for calcium malabsorption and osteoporosis? Scand J Gastroenterol. 2010;45: 133-8.

15. Goerss JB, Kim CH, Atkinson EJ, Eastell R, O'Fallon WM, Melton LJ. Risk of fractures in patients with pernicious anemia. J Bone Miner Res. 1992;7:573-9.

16. Kim HW, Kim YH, Han K, Nam GE, Kim GS, Han BD, et al. Atrophic gastritis: a related factor for osteoporosis in elderly women. PLoS One. 2014;9:e101852.

17. Aasarød KM, Mosti MP, Stunes AK, Reseland JE, Basso T, Syversen U, et al. Impaired skeletal health in patients with chronic atrophic gastritis. Scand J Gastroenterol. 2016;51:774-81.

18. Recker RR. Calcium absorption and achlorhydria. N Engl J Med. 1985;313:70-3.

19. Ivanovich P, Fellows H, Rich C. The absorption of calcium carbonate. Ann Intern Med. 1967;66:917-23.

20. Eastell R, Vieira NE, Yergey AL, Wahner HW, Silverstein MN, Kumar R, et al. Pernicious anaemia as a risk factor for osteoporosis. Clin Sci (Lond). 1992:82:681-5.

21. Massironi S, Cavalcoli F, Rossi RE, Conte D, Spampatti MP, Ciafardini C, et al. Chronic autoimmune atrophic gastritis associated with primary hyperparathyroidism: a transversal prospective study. Eur J Endocrinol. 2013; 168:755-61.

22. Antico A, Tozzoli R, Giavarina D, Tonutti E, Bizzaro N. Hypovitaminosis D as predisposing factor for atrophic type a gastritis: a case-control study and review of the literature on the interaction of vitamin $D$ with the immune system. Clin Rev Allergy Immunol. 2012;42:355-64.

23. Dixon MF, Genta RM, Yardley JH, Correa P. Classification and grading of gastritis. The updated Sydney system. International workshop on the histopathology of gastritis, Houston 1994. Am J Surg Pathol. 1996;20:1161-81.

24. Solcia E, Fiocca R, Villani L, Luinetti O, Capella C. Hyperplastic, dysplastic, and neoplastic enterochromaffin-like-cell proliferations of the gastric mucosa. Classification and histogenesis. Am J Surg Pathol. 1995;19:S1-7.

25. Marignani M, Delle Fave G, Mecarocci S, Bordi C, Angeletti S, D'Ambra G, et al. High prevalence of atrophic body gastritis in patients with unexplained microcytic and macrocytic anemia: a prospective screening study. Am J Gastroenterol. 1999;94:766-72.

26. Rugge M, Pennelli G, Pilozzi E, Fassan M, Ingravallo G, Russo VM, et al. Gastritis: the histology report. Dig Liver Dis. 2011;43(Suppl 4):S373-84.

27. Solcia E, Fiocca R, Villani L, Gianatti A, Cornaggia M, Chiaravalli A, et al. Morphology and pathogenesis of endocrine hyperplasias, precarcinoid lesions, and carcinoids arising in chronic atrophic gastritis. Scand J Gastroenterol Suppl. 1991;180:146-59.

28. Swami S, Raghavachari N, Muller UR, Bao YP, Feldman D. Vitamin D growth inhibition of breast cancer cells: gene expression patterns assessed by CDNA microarray. Breast Cancer Res Treat. 2003;80:49-62.
29. Whitfield GK, Jurutka PW, Haussler CA, Hsieh JC, Barthel TK, Jacobs ET, Dominguez CE, Thatcher ML, Haussler MR. Nuclear Vitamin D Receptor: Structure-Function, Molecular Control of Gene Transcription, and Novel Bioactions. in: Feldman D, Pike JW, Glorieux FH, editors. Vitamin D. vol. 1. Oxford: Elsevier Academic Press; 2005. pp. 219-261. https://doi.org/10.1016/ B978-012252687-9/50016-4.

30. Leyssens C, Verlinden L, Verstuyf A. Antineoplastic effects of 1,25(OH)2D3 and its analogs in breast, prostate and colorectal cancer. Endocr Relat Cancer. 2013;20:R31-47.

31. Feldman D, Krishnan AV, Swami S, Giovannucci E, Feldman BJ. The role of vitamin D in reducing cancer risk and progression. Nat Rev Cancer. 2014;14:342-57.

32. Jacobs ET, Kohler LN, Kunihiro AG, Jurutka PW. Vitamin D and colorectal, breast, and prostate cancers: a review of the epidemiological evidence. J Cancer. 2016;7:232-40.

33. Massironi S, Zilli A, Bernasconi S, Fanetti I, Cavalcoli F, Ciafardini C, et al. Impact of vitamin $\mathrm{D}$ on the clinical outcome of gastro-Entero-pancreatic neuroendocrine neoplasms: report on a series from a single institute. Neuroendocrinology. 2017;105:403-11.

34. Yu EW, Bauer SR, Bain PA, Bauer DC. Proton pump inhibitors and risk of fractures: a meta-analysis of 11 international studies. Am J Med. 2011;124:519-26.

35. Bo-Linn GW, Davis GR, Buddrus DJ, Morawski SG, Santa Ana C, Fordtran JS. An evaluation of the importance of gastric acid secretion in the absorption of dietary calcium. J Clin Invest. 1984;73:640-7.

36. Knox TA, Kassarijian Z, Dawson-Hughes B, Golner BB, Dallal GE, Arora S, et al. Calcium absorption in elderly subjects on high- and low-fiber diets: effect of gastric acidity. Am J Clin Nutr. 1991;53:1480-6.

37. Adachi Y, Shiota E, Matsumata T, Iso Y, Yoh R, Kitano S. Bone mineral density in patients taking H2-receptor antagonist. Calcif Tissue Int. 1998;62:283-5.

38. Kakehasi AM, Carvalho AV, Maksud FA, Barbosa AJ. Serum levels of vitamin B12 are not related to low bone mineral density in postmenopausal Brazilian women. Rev Bras Reumatol. 2012;52:863-9.
Ready to submit your research? Choose BMC and benefit from:
- fast, convenient online submission
- thorough peer review by experienced researchers in your field
- rapid publication on acceptance
- support for research data, including large and complex data types
- gold Open Access which fosters wider collaboration and increased citations
- maximum visibility for your research: over $100 \mathrm{M}$ website views per year
At BMC, research is always in progress.
Learn more biomedcentral.com/submissions 